\title{
Inhibition of Acetylcholinesterase by Coumarin-Linked Amino Acids Synthetized via Triazole Associated with Molecule Partition Coefficient
}

\author{
Bianca L. de Sousa, ${ }^{\oplus a}$ João P. V. Leite, ${ }^{b}$ Tiago A. O. Mendes, ${ }^{b}$ Eduardo V. V. Varejão, ${ }^{a}$ \\ Anna C. S. Chaves, ${ }^{a}$ Júnio G. da Silva, ${ }^{c}$ Ana P. Agrizzi, ${ }^{b}$ Priscila G. Ferreira, ${ }^{b}$ \\ Eduardo J. Pilau, ${ }^{\oplus d}{ }^{\text {Evandro Silva }}{ }^{\circledR d}$ and Marcelo H. dos Santos ${ }^{\circledR} *, a$
}

${ }^{a}$ Departamento de Química, Universidade Federal de Viçosa, Avenida Peter Henry Rolfs, s/n, Campus Universitário, 36570-900 Viçosa-MG, Brazil

${ }^{b}$ Departamento de Bioquímica e Biologia Molecular, Universidade Federal de Viçosa, Avenida Peter Henry Rolfs, s/n, Campus Universitário, 36570-900 Viçosa-MG, Brazil

${ }^{c}$ Departamento de Química, Universidade Federal de Minas Gerais, Av. Antônio Carlos, 6627, Pampulha, 31270-901 Belo Horizonte-MG, Brazil

${ }^{d}$ Departamento de Química, Universidade Estadual de Maringá, Avenida Colombo, 5790, Campus Universitário, 87020-900 Maringá-PR, Brazil

\begin{abstract}
A previous study for the identification of acetylcholinesterase (AChE) inhibitors demonstrated that the hybrid between tyrosol, the 1,2,3-triazole nucleus, and the coumarin group, namely 7-(\{1-[2-(4-hydroxyphenyl)ethyl]-1H-1,2,3-triazol-4-yl $\}$ methoxy)-4-methyl-2H-chromen-2-one (10), has a high enzyme inhibitory activity. Here, we synthesized analogues of $\mathbf{1 0}$ via triazole with pharmacophoric groups represented by tyrosine, phenylalanine, tryptophan, and glycine in addition to evaluating the impact of coumarin-linked amino acids on AChE inhibition. We obtained eight triazoles, six of which are undescribed. In general, the presence of carboxylic acid decreased the inhibitory activity, while aromatic amino acids increased enzymatic inhibition compared to glycine. The derivative containing tyrosine, structurally most similar to $\mathbf{1 0}$, presented the lowest inhibition percentage, indicating that phenolic hydroxyl is not the preponderant factor for inhibition. Molecular docking was not enough to explain in vitro experiments. On the other hand, $\mathrm{M} \log \mathrm{P}(\log \mathrm{P}$ calculated by the Moriguchi method) was related positively to enzymatic inhibition. To increase the hydrophobicity of the molecules, we tested the esterified triazole derivatives comparatively with the enzyme. The compound ethyl 2-(4-((4-methyl-2-oxo-2H-chromen-7-yl)oxy)methyl)$1 H$-1,2,3-triazol-1-yl)acetate (6) presented an increment of inhibitory activity of $46.97 \pm 1.75 \%$ at $100 \mu \mathrm{mol} \mathrm{L}^{-1}$. We also associated the best activity with the lowest van der Waals volume and molar mass values.
\end{abstract}

Keywords: amino acid, 1,2,3-triazoles, acetylcholinesterase, coumarin

\section{Introduction}

Coumarins are a large class of compounds naturally found in plants, bacteria, and fungi ${ }^{1,2}$ that display a wide range of interesting biological properties. ${ }^{3-5}$ Among these biological activities are antioxidant, ${ }^{6,7}$ anticancer, ${ }^{8,9}$ antimicrobial, ${ }^{10,11}$ anti-leishmanial, ${ }^{12,13}$ anti-tuberculosis, ${ }^{14,15}$ and therapeutic effects against Alzheimer's disease. ${ }^{16,17}$ These compounds are known to make noncovalent interactions, such as hydrophobic,

*e-mail: marceloh.santos@ufv.br $\pi$-type, and hydrogen bonding. ${ }^{18,19}$ The capacity to bind to multiple targets, including amino acid residues, makes coumarin derivatives promising in the development of new drugs and agrochemicals. ${ }^{20}$

In this context, molecular hybridization, a combination of biologically active molecules, has been shown to be an encouraging strategy to increase biological targets. ${ }^{21}$ Association between $2 \mathrm{H}$-chromen-2-one core and the 1,2,3-triazole moiety has shown more pharmacologically active coumarins. ${ }^{2,8,22}$ Within the universe of click chemistry, the synthesis of 1,2,3-triazoles has been studied as a method for obtaining new compounds..$^{23,24}$ This pharmacophoric 
group $^{25}$ is propitious because it presents several biological activities such as antimicrobial, ${ }^{26,27}$ antiprotozoal, ${ }^{28,29}$ anticancer ${ }^{24,30,31}$ activities, as well as enzyme inhibition, as is the case with elastase and acetylcholinesterase (AChE) ${ }^{22,23,32}$ For example, Moradi et al. ${ }^{33}$ synthesized a new series of coumarin and benzylamine hybrids, linked via the triazole ring, and evaluated the compounds as inhibitors of AChE and butyrylcholinesterase (BChE). Among the compounds, 7-((1-(3-methoxybenzyl)-1H-1,2,3-triazol4-yl)methoxy)- $2 H$-chromen-2-one was the most active, presenting half maximal inhibitory concentration $\left(\mathrm{IC}_{50}\right)$ values of 3.4 and $1.1 \mu \mathrm{mol} \mathrm{L^{-1 }}$ for $\mathrm{AChE}$ and $\mathrm{BChE}$, respectively.

In previous works, ${ }^{23,24,32}$ our research group was involved in the investigation of derivatives containing the 1,2,3-triazole nucleus. Tyrosol-derived triazoles, a tyrosine analogue biophenol, were evaluated as AChE inhibitors. The compound containing the coumarin group, namely 7-(\{1-[2-(4-hydroxyphenyl)ethyl]-1H-1,2,3-triazol-4-yl $\}$ methoxy)-4-methyl-2H-chromen-2-one (10) exhibited a high inhibitory effect, reducing $67.8 \pm 5.8 \%$ of enzyme activity at $50 \mu \mathrm{mol} \mathrm{L}^{-1} .32$

Amino acids perform different functions in the organism. ${ }^{34}$ Among these macromolecules stands out the tyrosine, which is a synthetic precursor of tyrosol. ${ }^{35}$ The association between amino acids and organic molecules is interesting because their association can qualitatively enhance some physicochemical properties, such as solubility, stability, and toxicity. ${ }^{36,37}$ Furthermore, amino acids have been reported in the development of prodrugs due to their propensity to be transported across biological membranes, increasing bioavailability. ${ }^{38}$ Hybrids between coumarins and amino acid have already been reported to have enzymatic inhibition capabilities ${ }^{39}$ and antimicrobial activity. ${ }^{40}$ However, the use of amino acids in organic chemistry is still scarce due to the difficulties of working with polar molecules while using typically nonpolar solvents.

In this present study, it was proposed the esterification of amino acids as a way of increasing the carbon chain and, consequently, the solubility in organic solvents. The last stage of the synthesis was the hydrolysis of the esters to obtain coumarin-linked amino acids. Thus, considering that the associated coumarin derivatives and triazole rings exhibit several biological properties, we reported on the synthesis of a new series hybrids of $\mathbf{1 0}$, containing 4-methylumbelliferone, 1,2,3-triazole moiety, and amino acids, esterified or not (Figure 1). In vitro studies were also performed in the presence of $\mathrm{AChE}$ to determine their

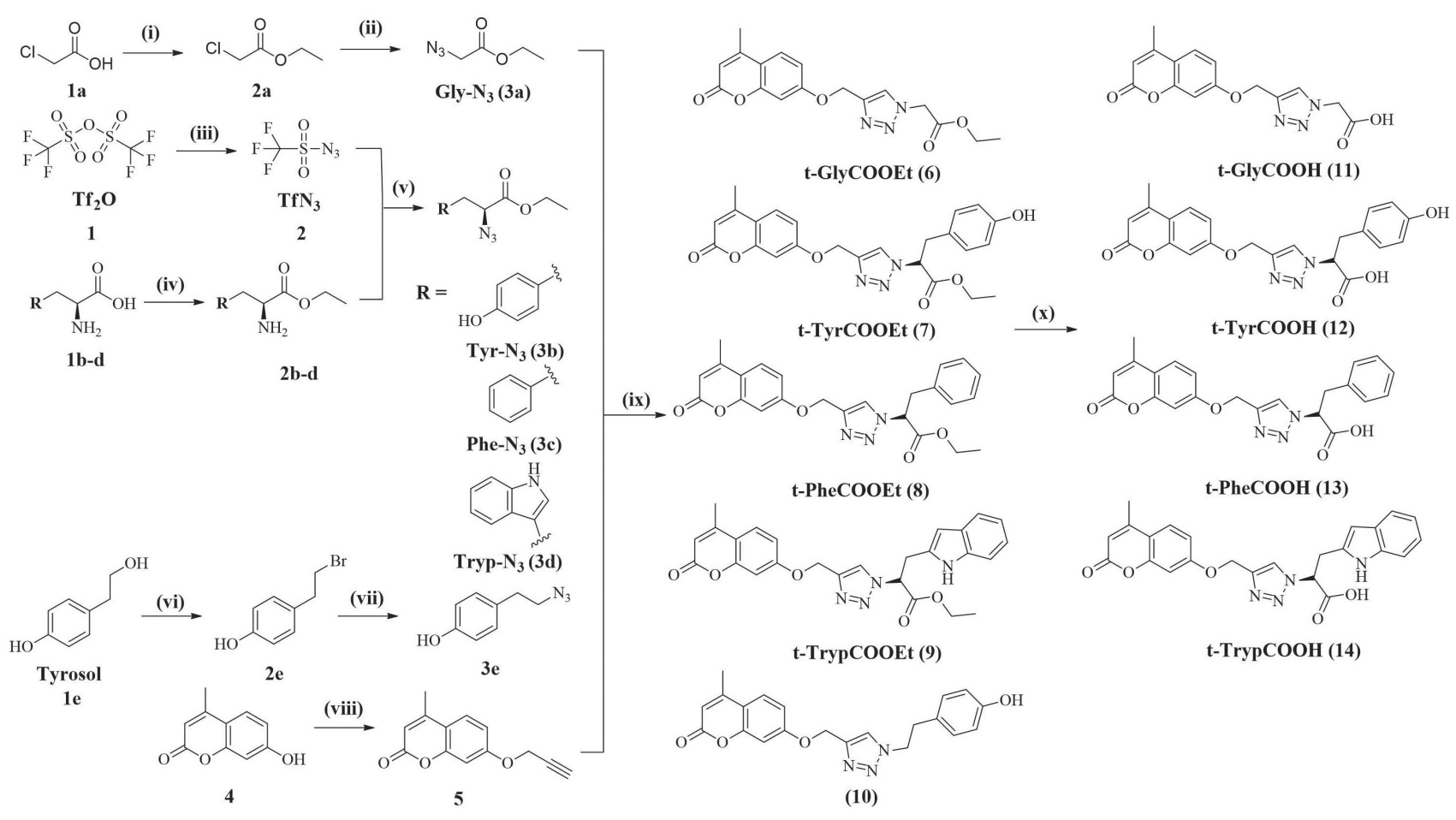

Figure 1. Synthetic steps involved in the preparation of triazole-derived azide amino acids. Reagents and conditions: (i) anhydrous dichloromethane (DCM), thionyl chloride $\left(\mathrm{SOCl}_{2}, 1.2\right.$ eq.), ethanol (4.8 eq.), r.t., $30 \mathrm{~min}, 83 \%$ yield; (ii) sodium azide (2.0 eq.), dimethyl sulfoxide (DMSO), r.t., $12 \mathrm{~h}$; (iii) sodium azide (5.0 eq.), DCM/ $\mathrm{H}_{2} \mathrm{O}(2: 1 \mathrm{v} / \mathrm{v})$, r.t., $2 \mathrm{~h}$; (iv) $20 \%$ (v/v) ethanolic $\mathrm{H}_{2} \mathrm{SO}_{4}$ solution $\left(60{ }^{\circ} \mathrm{C}\right.$, 96-98\% yield range; (v) $\mathrm{NaHCO}_{3}(10.0$ eq. $), \mathrm{CuSO}_{4} .5 \mathrm{H}_{2} \mathrm{O}$ (0.10 eq.), DCM/ $\mathrm{H}_{2} \mathrm{O} /$ methanol (2:1:1 v/v) r.t., $24 \mathrm{~h}$; (vi) $\mathrm{HBr} 48 \%$ (m/m), 70-80 ${ }^{\circ} \mathrm{C}, 70 \%$ yield; (vii) sodium azide (1.5 eq.), dimethylacetamide (DMAC), r.t., 4-5 h; (viii) propargyl bromide (1.5 eq.), anhydrous $\mathrm{K}_{2} \mathrm{CO}_{3}\left(2.0\right.$ eq.), anhydrous acetonitrile, $50{ }^{\circ} \mathrm{C}, 24 \mathrm{~h} ; 77 \%$ yield; $(i x) \mathrm{CuSO}_{4} .5 \mathrm{H}_{2} \mathrm{O}(0.20$ eq.), sodium ascorbate (0.40 eq.), ethyl ether (1) or ethyl acetate (2 and 4) or DCM (3)/ $\mathrm{H}_{2} \mathrm{O}(8: 1 \mathrm{v} / \mathrm{v})$, r.t., $14 \mathrm{~h}, 58-93 \% ;(x) 20 \% \mathrm{~m} / \mathrm{v} \mathrm{NaOH} \mathrm{solution}(5 \mathrm{~mL})$, ethanol, r.t., 3 h, $57-98 \%$ yield range. 
inhibitory capability. We hypothesized that the aromatic amino acid derivatives generate better inhibitors than aliphatic derivatives, due to a pharmacophoric similarity with tyrosol.

\section{Results and Discussion}

Amino acid-derived organic azides were chosen for molecular hybridization with propargylated 4-methylumbelliferone (5) to produce a series of derivatives containing a triazole ring as linker (6-9, Figure 1$)$. The aromatic amino acid-derived azides, obtained from tyrosine, phenylalanine, tryptophan esterified (2b-2d) were used due to the similarity to tyrosol. Azides from these monomers were obtained for a diazo transfer reaction (v), with the configuration retention, ${ }^{41}$ using trifluoromethanesulfonyl azide $\left(2, \mathrm{TfN}_{3}\right)$. In addition, to verify the influence of the aromatic portion on the cholinesterase action of the compounds, we promote the synthesis of a derivative without this portion (glycine analogues, 6 and 11). For such, the ethyl 2-chloroacetate (2a) was utilized to produce the glycine analog-derived azide (3a). Concomitantly to azides production, the propargylation reaction of 4-metilumbeliferone (viii) was performed, producing the alkyne, 7-hydroxy-4-methyl-2 $\mathrm{H}$-chromen-2-one (5), in $77 \%$ yield. Finally, triazoles $(\mathbf{6}-\mathbf{1 0})$ were synthesized from azides (3a-3e) and alkyne $\mathbf{5}$ via copper(I)-catalyzed azidealkyne cycloaddition reaction (CuAAC) in yields ranging from 58 to $93 \%$. All triazolic derivatives were characterized through infrared (IR) and nuclear magnetic resonance $\left({ }^{1} \mathrm{H}\right.$ and ${ }^{13} \mathrm{C}$ NMR) spectroscopies as well as high-resolution mass spectrometry (HRMS), and specific rotation, $[\alpha]_{D}$. The spectra are presented in the Supplementary Information section. The characterization of $\mathbf{6}$ and $\mathbf{1 0}$ are in accordance with Kumari et al..$^{42}$ and Bousada et al., ${ }^{32}$ respectively. In the ${ }^{1} \mathrm{H}$ NMR spectra, signals of hydrogen atoms from the esterification were observed as a triplet and a quartet at the $\delta 1.18-1.29$ and $\delta 1.29-4.26$ ranges, respectively. The allyl hydrogens match with signals at the $\delta$ 5.18-5.22 range. The signals of vinyl hydrogens in the coumarin nucleus and the triazolic rings were observed at the $\delta 6.11-6.14$ and $\delta$ 7.52-7.82 range, respectively. The carbon chemical shifts in ${ }^{13} \mathrm{C}$ NMR are consistent with the compound structures.

Subsequently, the triazoles were subjected to basic hydrolysis to obtain derivatives containing carboxylic acids (11-14) in yields ranging from 57-98\%. These molecules are interesting because they presented similarities with glycine (11), tyrosine (12), phenylalanine (13), and tryptophan (14), all of which are biologically-active molecules. The obtained compounds were characterized using the same techniques used for triazoles 6-10. In the
${ }^{1} \mathrm{H}$ NMR spectra, the signals of hydrogen atoms at the 1.18-1.29 and 1.29-4.26 range are absent, confirming hydrolysis. The carbon and hydrogen chemical shifts in ${ }^{13} \mathrm{C}$ and ${ }^{1} \mathrm{H}$ NMR are consistent with the compound structures.

\section{Molecular docking}

Molecular docking was used to predict intermolecular interactions between the triazoles and acetylcholinesterase. The docking analysis was carried out with five compounds (10-14). We choose the enzyme Torpedo californica AChE to compare with data from Bousada et al. ${ }^{32}$ The energies for the best molecular orientation for the interactions between the ligands and the enzyme are presented in Table 1.

Table 1. Interaction affinity energy of the ligands for the molecular arrangements with lowest energies

\begin{tabular}{lc}
\hline Compound & Interaction affinity energy / $\left(\mathrm{kcal} \mathrm{mol}^{-1}\right)$ \\
\hline $\mathbf{1 0}($ reference $)$ & -12.0 \\
$\mathbf{1 1}(\mathrm{t}-\mathrm{GlyCOOH})$ & -10.2 \\
$\mathbf{1 2}(\mathrm{t}-\mathrm{TyrCOOH})$ & -11.5 \\
$\mathbf{1 3}(\mathrm{t}-\mathrm{PheCOOH})$ & -11.1 \\
$\mathbf{1 4}(\mathrm{t}-$ TrypCOOH) & -8.8 \\
\hline
\end{tabular}

Molecular docking was also used to assess how many different positions each ligand can occupy at the catalytic site and which amino acids they interact with. The active site of the Torpedo californica acetylcholinesterase is composed of Ser200, His440, and Glu327 (catalytic triad); Trp84, Tyr130, Phe330, and Phe331 (anionic site); Phe288 and Phe290 (acyl pocket); Gly118, Gly119, and Ala201 (oxyanion hole); Asp72, Tyr70, Tyr121, Trp279, and Tyr334 (peripheral anionic site-PAS). ${ }^{43}$

Ligand-receptor interactions for triazoles are demonstrated in Figure 2 as well as the pharmacophoric map of compound 10. All molecules interact with many amino acid active sites, including Phe330. Furthermore, amino acid-derived triazoles and $\mathbf{1 0}$ exhibited different interactions with the PAS portion, related to the binding of many inhibitors. ${ }^{43}$

The molecular docking revealed that the compounds present affinities for the Torpedo californica acetylcholinesterase similarly to $\mathbf{1 0}$, and most often outnumber the amino acid interactions at the catalytic site when compared to 10. For example, (12) presented a conventional hydrogen bond with Asn85 and Ser122, which can hinder substrate-enzyme interaction (Figure 2). So, we decided to test the amino acid-derived triazoles against acetylcholinesterase in vitro. 


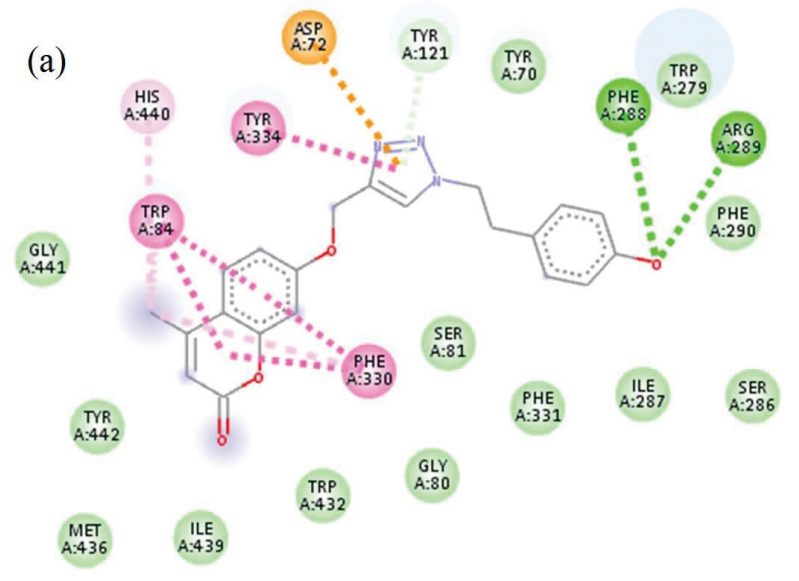

(10)

(c)

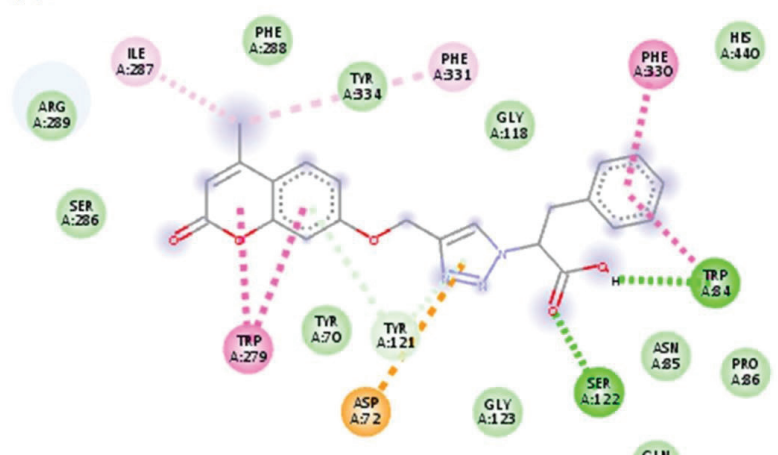

(13)

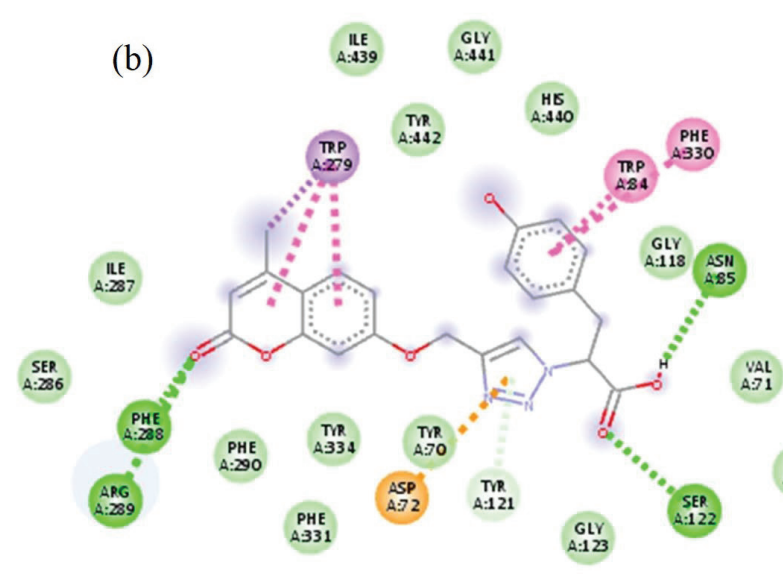

(d)

(12)

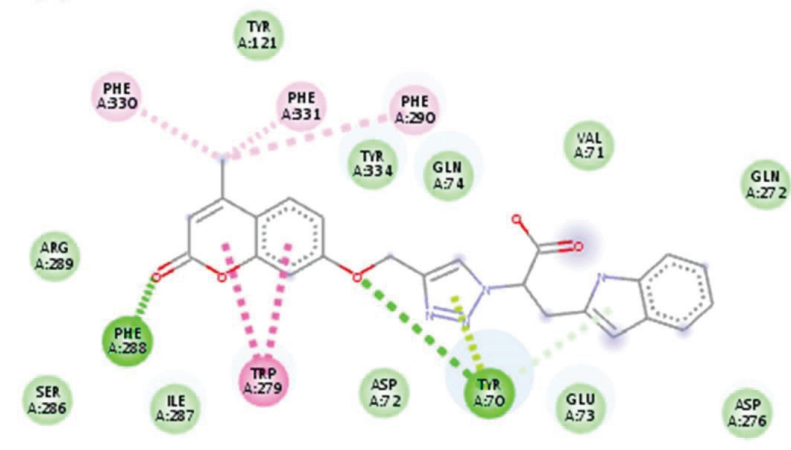

(14)

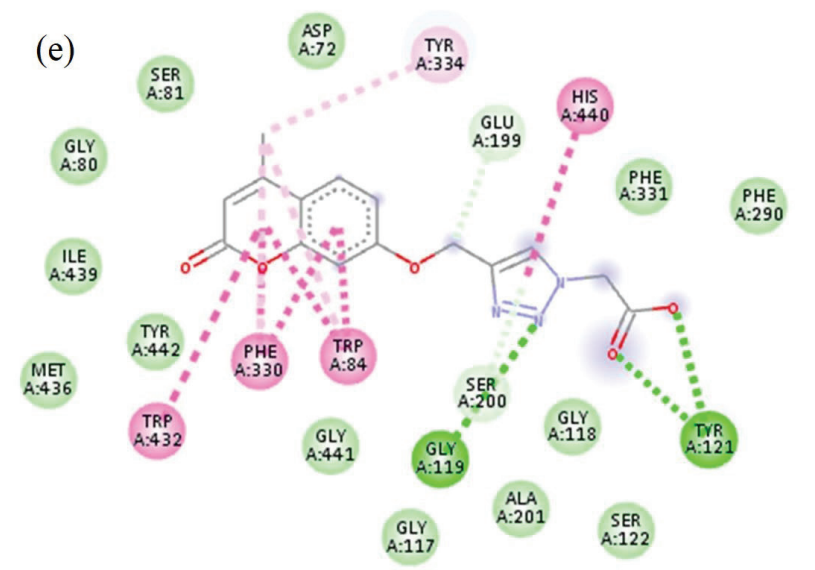

Interactions
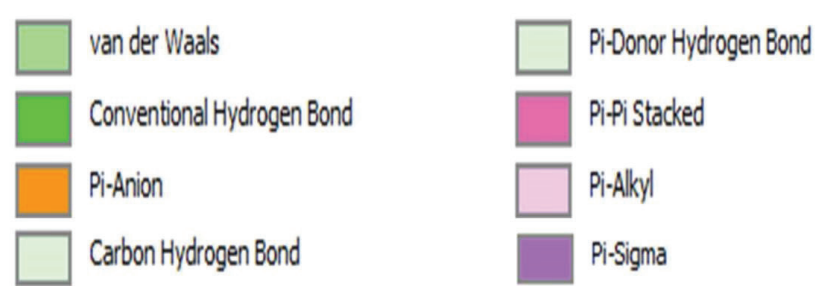

Pi-Lone Pair

(11)

Figure 2. Pharmacophore map of ligand-receptor interactions for coumarin-linked tyrosol (10) and coumarin-linked amino acids (tyrosine, phenylalanine, tryptophan, and glycine). (a) Reference (10); (b) t-TyrCOOH (12); (c) t-PheCOOH (13); (d) t-TrypCOOH (14); (e) t-GlyCOOH (11).

\section{Enzymatic inhibition assay}

The acetylcholinesterase inhibition assay was initially performed with the triazole derivatives (11-14) as well as compound 10. The experiments were performed with compounds at the concentrations of 50,100, and
$200 \mu \mathrm{mol} \mathrm{L}{ }^{-1}$. The percentages of inhibition of AChE by $\mathbf{1 0}$ are in accordance with the results obtained by Bousada et al. ${ }^{32}$

Triazoles derived from aromatic amino acids were more active against acetylcholinesterase when compared to t-GlyCOOH (11), which inhibited only $15.84 \pm 1.51 \%$ 
at $200 \mu \mathrm{mol} \mathrm{L} \mathrm{L}^{-1}$ (Table 2). Thus, the presence of aromatic amino acids associated with the coumarin nucleus via triazole tends to increase enzymatic inhibition in relation to aliphatic amino acids. This fact corroborates our initial hypothesis.

The presence of tryptophan and phenylalanine in triazoles formed inhibitors with higher potential than tyrosine. Compound $\mathbf{1 4}$ (t-TrypCOOH) inhibited $29.33 \pm 1.45 \%$ of enzymatic activity, followed by $\mathbf{1 3}$ (t-PheCOOH), with $21.32 \pm 1.90 \%$, and $\mathbf{1 2}(\mathrm{t}-\mathrm{TyrCOOH})$, with $17.78 \pm 0.84 \%$ at $100 \mu \mathrm{mol} \mathrm{L}^{-1}$. So, compound $\mathbf{1 2}$, the structurally closest to $\mathbf{1 0}$, presented the lowest inhibition percentage, indicating that the presence of phenolic hydroxyl is not the preponderant factor for inhibition. Derivative 10 reached $72.38 \pm 1.11 \%$ inhibition, while t-TyrCOOH reached only $23.77 \pm 3.10 \%$. The carboxylic acid group present in tyrosine seems to decrease enzymatic inhibition when connected to the coumarin nucleus via triazole.

Table 2. Influence of amino acids bound to the coumarin nucleus via triazole against the enzymatic activity of acetylcholinesterase (Electrophorus electricus, type VI). Enzyme inhibition percentage at 50,100 , and $200 \mu \mathrm{mol} \mathrm{L}^{-1}$, concentrations of each compound with their respective standard deviations. Different letters were used to compare the significance between compounds at the same concentration $(p<0.05$ according to analysis of variance (ANOVA) followed by Tukey's post-test)

\begin{tabular}{lccc}
\hline \multirow{2}{*}{ Compound } & \multicolumn{3}{c}{ Inhibition /\% } \\
\cline { 2 - 4 } & \multicolumn{3}{c}{ Concentration / $\left.(\mu \mathrm{mol} \mathrm{L})^{-1}\right)$} \\
\cline { 2 - 4 } & 50 & 100 & 200 \\
\hline $\mathbf{1 0}$ (reference) & $63.94 \pm 3.08^{\mathrm{a}}$ & $65.90 \pm 1.13^{\mathrm{a}}$ & $72.38 \pm 1.11^{\mathrm{a}}$ \\
$\mathbf{1 4}(\mathrm{t}-$ TrypCOOH) & $17.25 \pm 1.56^{\mathrm{b}}$ & $29.33 \pm 1.45^{\mathrm{b}}$ & $43.26 \pm 1.43^{\mathrm{b}}$ \\
$\mathbf{1 3}(\mathrm{t}-\mathrm{PheCOOH})$ & $12.66 \pm 2.19^{\mathrm{c}}$ & $21.32 \pm 1.90^{\mathrm{c}}$ & $34.13 \pm 3.54^{\mathrm{c}}$ \\
$\mathbf{1 2}(\mathrm{t}-\mathrm{TyrCOOH})$ & $10.20 \pm 1.00^{\mathrm{c}}$ & $17.78 \pm 0.84^{\mathrm{d}}$ & $23.77 \pm 3.10^{\mathrm{d}}$ \\
$\mathbf{1 1}(\mathrm{t}-\mathrm{GlyCOOH})$ & $4.63 \pm 0.87^{\mathrm{d}}$ & $8.06 \pm 1.11^{\mathrm{e}}$ & $15.84 \pm 1.51^{\mathrm{e}}$ \\
\hline Galantamine $^{\mathrm{a}}$ & \multicolumn{3}{c}{$89.2 \pm 1.0\left(17 \mu \mathrm{mol} \mathrm{L}^{-1}\right)$} \\
\hline
\end{tabular}

${ }^{\mathrm{a}}$ Galantamine was used as a positive control.

(a)

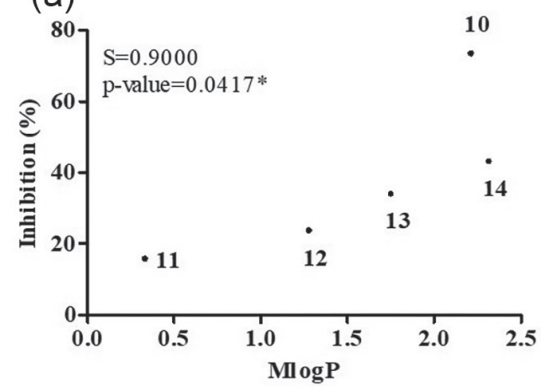

(b)

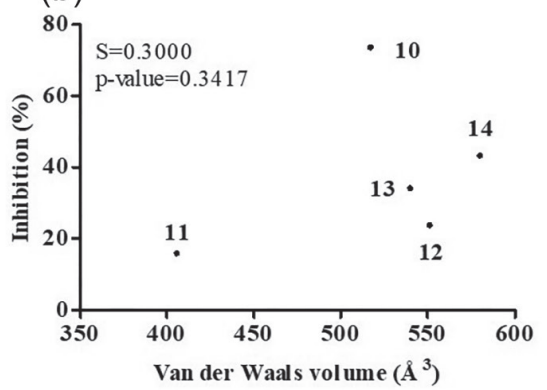

From these results, a question was raised: why amino acid-derived triazoles do not show inhibition against acetylcholinesterase comparable to $\mathbf{1 0}$ even while interacting in high affinity with the enzyme? This occurs because molecular docking is a computational simulation which assumes that there will be an interaction between a ligand and receptor, therefore, the simulation attempts to make it happen. In that regard, some parameters are not taken into account in bioinformatics analysis, like solubility. The in vitro activities are realized in methanol and water, influencing the migration of the inhibitors to the active center of the enzyme. ${ }^{44,45}$ Besides this, the docking assay does not consider the different conformations that the enzyme may have, regarding it as a rigid structure. ${ }^{32}$

In short, differences between biological assays and docking results can be associated with the physicochemical characteristics of the compounds..$^{32,46,47}$ In that regard, the compounds were evaluated for the possible structure-activity relationship. We evaluate three characteristics: (i) MlogP ( $\log \mathrm{P}$ calculated by the Moriguchi method), (ii) van der Waals volume, and (iii) molar mass (Figure 3). MlogP is related to enzymatic inhibition according to the Spearman test ( $p$-value $<0.05$ ), confirming once again the initial hypothesis that $\mathrm{t}$-GlyCOOH (11) would be the least potent inhibitor.

The MlogP may be related to inhibitor interactions within hydrophobic amino acids in the enzyme. This idea is supported by the fact that the anionic site and the PAS site, related to the binding of many inhibitors, are formed by 100 and $80 \%$ of aromatic amino acids, respectively. The $\mathrm{AChE}$ anionic site is of paramount importance because the proper orientation of acetylcholine in the gorge. ${ }^{43}$

The aromatic character of the gorge might contribute to the high catalytic activity. The aromatic lining can be associated with initial absorption of ligand to low-affinity sites, followed by rapid diffusion to the active site. ${ }^{51}$ Besides, the anionic and hydrophobic subsites confer specificity for alkyl (R) groups and stabilize the methyl group of the acetylcholine. ${ }^{52}$

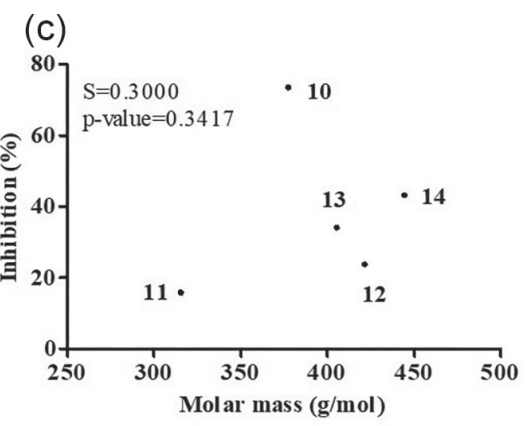

Figure 3. The relation between the AChE inhibition (\%) and physicochemical parameters of the amino acids linked to the triazole nucleus at $200 \mu \mathrm{mol} \mathrm{L}^{-1}$.

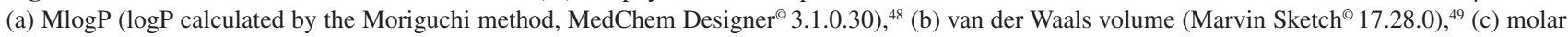
mass (ChemDraw Ultra ${ }^{\odot}$ 12.0.2.1076). $.0 * p<0.05$ according to nonparametric correlation (Spearman). 
The high activity of compound $\mathbf{1 0}$ against acetylcholinesterase can be associated with the greatest hydrophobicity. To confirm this, we decided to verify whether increasing MlogP values would increase the inhibitory activity against acetylcholinesterase. With that, we also tested the hypothesis that the presence of carboxylic acid in the derivatives decreases this activity. We tested the esterified triazole derivatives against the enzyme. Due to solubility in methanol compounds, concentrations were 50 and $100 \mu \mathrm{mol} \mathrm{L}^{-1}$. MlogP, van der Waals volume, and molar mass values are presented in Table 3 .

Table 3. Comparison between $\mathrm{M} \log \mathrm{P}(\log \mathrm{P}$ calculated by the Moriguchi method), van der Waals volume, and molar mass values of triazoles derived from esterified (6-9) and non-esterified (11-14) amino acids

\begin{tabular}{lccc}
\hline Compound & MlogP & $\begin{array}{c}\text { van der Waals } \\
\text { volume / } \AA^{3}\end{array}$ & $\begin{array}{c}\text { Molar mass / } \\
\left(\mathrm{g} \mathrm{mol}^{-1}\right)\end{array}$ \\
\hline $\mathbf{9}$ (t-TrypCOOEt) & 2.721 & 649.51 & 472.49 \\
$\mathbf{8}$ (t-PheCOOEt) & 2.176 & 609.43 & 433.46 \\
$\mathbf{7}$ (t-TyrCOOEt) & 1.705 & 620.79 & 449.46 \\
$\mathbf{6}$ (t-GlyCOOEt) & 0.825 & 474.97 & 343.33 \\
$\mathbf{1 4}$ (t-TrypCOOH) & 2.315 & 579.86 & 444.44 \\
$\mathbf{1 3}$ (t-PheCOOH) & 1.750 & 539.77 & 405.40 \\
$\mathbf{1 2}$ (t-TyrCOOH) & 1.279 & 550.90 & 421.40 \\
$\mathbf{1 1}$ (t-GlyCOOH) & 0.332 & 405.65 & 315.28 \\
\hline
\end{tabular}

MlogP, van der Waals volume and molar mass were calculated by the MedChem Designer ${ }^{\odot}$ 3.1.0.30, ${ }^{48}$ Marvin Sketch $^{\odot} 17.28 .0^{49}$ and ChemDraw Ultra $^{\odot}$ 12.0.2.1076, ${ }^{50}$ respectively.

Only half of the compounds increased their activities compared to their analogues. The compounds t-PheCOOEt (8) and t-GlyCOOEt (6) were 60 and $480 \%$ more active than t-PheCOOH (13) and t-GlyCOOH (11) at $100 \mu \mathrm{mol} \mathrm{L}^{-1}$,

(a)

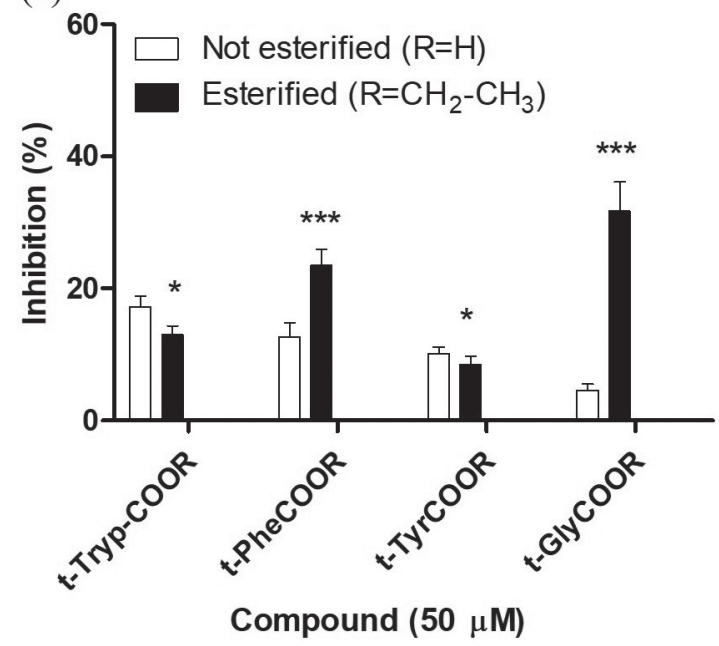

respectively (Figure 4). The other triazoles decreased their inhibitory activities against acetylcholinesterase when acetylated.

We believe that the increase in the physicochemical parameters could have influenced the inhibitory activity, both positively and negatively. In fact, the increase in MlogP resulted in an enhancement of the inhibitory activity of t-GlyCOOEt (6) and t-PheCOOEt (8), but this positive correlation was not observed for molecules derived from tryptophan (9) and tyrosine (7). Between esterified amino acids, triazoles derived from phenylalanine (8) and glycine (6) presented the lowest van der Waals volume and molar mass values compared to the other esterified compounds. t-GlyCOOEt (6) exhibited van der Waals volume and a molar mass approximately 28 and $26 \%$ less than t-PheCOOEt $(\mathbf{8})$, respectively. The low values for these parameters represent greater degrees of conformational freedom for structures within the enzymatic active site. Therefore, the substrate enzyme interaction is more likely to be optimized since more conformational possibilities are allowed. On the other hand, although the esterification of t-TyrCOOH (12) and t-TrypCOOH (14) also resulted in an increase of MlogP, they were accompanied by the increase of the others parameters as well, such as Waals volume and molar mass. These parameters may have breached a limiting value which permits optimal interaction with the enzyme, thus reducing their activities.

\section{Conclusions}

Once the biological activities of the coumarin nucleus were reported, and once our research group discovered the inhibitory activity of AChE by triazoles

(b)

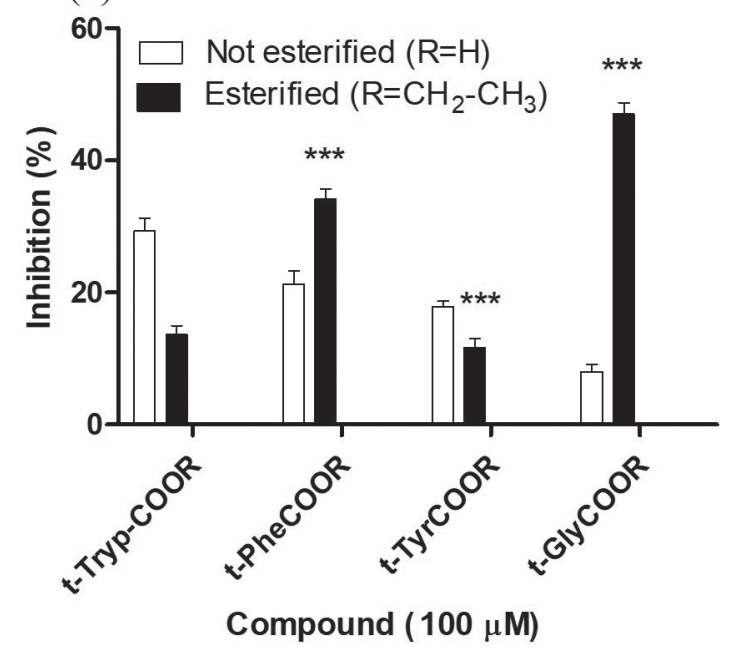

Figure 4. Influence of acetylation of triazole derivatives against acetylcholinesterase (Electrophorus electricus, type VI). (a) Enzyme inhibition percentage at $50 \mu \mathrm{mol} \mathrm{L}{ }^{-1}$; (b) enzyme inhibition percentage at $100 \mu \mathrm{mol} \mathrm{L} \mathrm{L}^{-1}$.*** $p<0.005, * p<0.05$ according to $t$-test. 
containing this nucleus, 7-(\{1-[2-(4-hydroxyphenyl)ethyl]$1 H$-1,2,3-triazol-4-yl \}methoxy)-4-methyl-2H-chromen2-one (10) analogues were synthesized in the present study. Tyrosine, phenylalanine, tryptophan, and glycine were linked to a coumarin group via triazole and evaluated against AChE. Possible structure-activity relationship indicated that phenolic hydroxyl is not the preponderant factor for inhibition. Additionally, the presence of aromatic amino acids improves the inhibitory effects compared to glycine. The presence of carboxylic acid in phenylalanine and glycine derivatives decreased the inhibition. Esterified triazole derivatives also were tested and the triazole containing glycine demonstrated the greatest difference in inhibition between the esterified (6) and non-esterified (11) forms, $46.97 \pm 1.75 \%$, and $8.06 \pm 1.11 \%$, at $100 \mu \mathrm{mol} \mathrm{L}^{-1}$, respectively. The physicochemical parameters related to molecular spatial dimension were the ones that best explained the relationship between structure and activity. These findings indicate the bioconjugation between the amino acid, the coumarin, and the triazole can be considered an important foundation for further studies on AChE inhibition.

\section{Experimental}

\section{General procedure}

All reagents and solvents were purchased from Sigma-Aldrich (Saint Louis, Missouri, USA) and Vetec (Duque de Caxias, Rio de Janeiro, Brazil) and used without prior purification. Column chromatography was performed over silica gel 60 (70-230 mesh, Macherey-Nagel, Düren, Germany) as a stationary phase using a mixture of hexane/ethyl acetate as eluents. Analytical thin-layer chromatography (TLC) was performed on silica gel plates (Macherey-Nagel DC-Fertigfolien ALUGRAM ${ }^{\circledR}$ Xtra SIL G/UV254, Düren, Germany). ${ }^{1} \mathrm{H}$ NMR (300 MHz) and ${ }^{13} \mathrm{C}$ NMR (75 MHz) experiments were performed on a Bruker $300 \mathrm{MHz}$ equipment (Billerica, Massachusetts, USA) using $\mathrm{CDCl}_{3}$, dimethyl sulfoxide (DMSO- $d_{6}$ ), and $\left(\mathrm{CD}_{3}\right)_{2} \mathrm{CO}$ as solvents. The spectra were referenced using the solvent residual signals. ${ }^{1} \mathrm{H}$ NMR data are presented as follows: chemical shift $(\delta)$ in ppm, multiplicity, the number of hydrogens, and coupling constant $(J)$ values in hertz $(\mathrm{Hz})$. Multiplicities are shown as the following abbreviations: s (singlet), bs (broad singlet), d (doublet), dd (doublet of doublets), t (triplet), q (quartet), m (multiplet).

Melting temperature ( $\mathrm{mp}$ ) ranges were determined in Microchemical MQAPF-302 apparatus (Microquímica Equipamentos, Palhoça, Santa Catarina, Brazil). Attenuated total reflectance Fourier transform infrared (ATR-
FTIR) analyses were performed on a Varian 660-IR spectrophotometer equipped with a GladiATR apparatus (Varian, Palo Alto, California, USA).

HRMS were carried out on a high-resolution Q-TOF (quadrupole-time of flight) mass spectrometer Impact II geometry (Bruker Daltonics Corporation, Bremen, Germany) equipped with an electrospray ionization source (ESI). Samples were directly injected into the ESI source using a syringe pump (KDS Legato 100, KD Scientific, Holliston, Massachusetts, USA) at a flow rate of $10 \mu \mathrm{L} \mathrm{min}^{-1}$. The capillary voltage was operated in positive ion mode, set at $4000 \mathrm{~V}$ with an end plate offset potential of $-500 \mathrm{~V}$. The dry gas parameters were set to $8 \mu \mathrm{L} \mathrm{min}{ }^{-1}$ at $180^{\circ} \mathrm{C}$ with a nebulization gas pressure of 0.4 bar. Data were collected in the range of 50 to $800 \mathrm{~m} / \mathrm{z}$ in continuous acquisition mode. The mass spectra were obtained in the Data Analysis program 4.3 (Bruker Daltonics Corporation, Bremen, Germany).

Values of rotation angle $(\alpha)$ were measured on a polarimeter ADP220, serial no. PF05050 (Bellingham+Stanley Ltd., Tunbridge Wells, Kent, UK) using sodium as a monochromatic light source $(\lambda=598.3 \mathrm{~nm})$ at $25^{\circ} \mathrm{C}$ and an optical path of 0.5 decimeters. The final concentration $(c)$ of the solutions was calculated in $\mathrm{g} 100 \mathrm{~mL}^{-1}$.

\section{Synthesis of azides}

\section{Ethyl 2-azideacetate (Gly- $\left.\mathrm{N}_{3}, 3 a\right)$ preparation}

Azide 3a was obtained from ethyl 2-chloroacetate (2a) which, in turn, was produced from esterification of chloroacetic acid (1a). To produce 2a, $5.32 \mathrm{mmol}$ of chloroacetic acid and $10 \mathrm{~mL}$ of anhydrous dichloromethane (DCM) were transferred to a round-bottom flask on ice bath. Then, $6.38 \mathrm{mmol}$ (1.2 equiv.) of thionyl chloride were added dropwise and the mixture was kept under magnetic stirring for $5 \mathrm{~min}$. After this period, $1.5 \mathrm{~mL}$ of ethanol were added and the solution was stirred for $30 \mathrm{~min}$. At the end (as observed by TLC), the reaction was quenched by adding $5 \mathrm{~mL}$ of distilled water, and the obtained solution was washed with 3 times with $5 \mathrm{~mL}$ of diethyl ether. The organic phases were combined, dried over anhydrous magnesium sulfate, filtered, and concentrated on a rotary evaporator. Compound 2a was obtained in $83 \%$ yield with no need for additional purification.

For the synthesis of 3a, 2a $(2.04 \mathrm{mmol})$, sodium azide (4.08 mmol, 2 equiv.) and $2 \mathrm{~mL}$ of dimethyl sulfoxide (DMSO) were transferred to a round-bottomed flask and the mixture was kept under stirring for $12 \mathrm{~h}$. After this time, $5 \mathrm{~mL}$ of saturated $\mathrm{NaHCO}_{3}$ solution were added and the obtained solution was extracted with diethyl ether $(3 \times 5 \mathrm{~mL})$. The organic phases were combined, dried over 
anhydrous magnesium sulfate, filtered, and concentrated on a rotary evaporator. ${ }^{53}$ Compound 3a was obtained in $74 \%$ yield as a transparent oil without further purification.

General procedure for the preparation of (S)-ethyl 2-azido3-(4-hydroxyphenyl)propanoate (3b), (S)-ethyl 2-azido3-phenylpropanoate (3c) and (S)-ethyl 2-azido-3-(1 H-indol3-yl)propanoate (3d)

Tyr- $\mathrm{N}_{3}(\mathbf{3 b})$, Phe- $\mathrm{N}_{3}(\mathbf{3 c})$, and Tryp- $\mathrm{N}_{3}(\mathbf{3 d})$ azides were synthesized by reacting $\operatorname{TfN}_{3}(2)$ with tyrosine, tryptophan, and esterified phenylalanine, respectively. Firstly, $\mathrm{TfN}_{3}$ was prepared in situ from trifluoromethanesulfonic anhydride $\left(\mathrm{Tf}_{2} \mathrm{O}, \mathbf{1}\right)$ according to a reaction procedure described by Robillard et al. ${ }^{54}$ and used in solution only. ${ }^{55}$ For $\mathrm{TfN}_{3}$ synthesis, $\mathrm{Tf}_{2} \mathrm{O}(0.48 \mathrm{mmol})$ and $2 \mathrm{~mL}$ DCM were transferred to a round-bottomed flask, followed by dropwise addition of a solution of sodium azide $(2.4 \mathrm{mmol})$ in distilled water $(1 \mathrm{~mL})$. The mixture was kept under stirring for $2 \mathrm{~h}$ and then extracted with DCM $(3 \times 5 \mathrm{~mL})$. The organic phases were washed twice with $5 \mathrm{~mL}$ of $5 \%(\mathrm{~m} / \mathrm{v})$ aqueous $\mathrm{NaHCO}_{3}$ and concentrated to a volume of $3 \mathrm{~mL}$ under reduced pressure to obtain the triflylamino-transfer solution.

The amino acid esterifications were performed according to the methodology proposed by Laulloo ${ }^{56}$ with modification. Briefly, sulfuric acid $(200 \mu \mathrm{L})$ was added dropwise to a solution of each amino acid $(0.28 \mathrm{mmol})$ in ethanol $(1.8 \mathrm{~mL})$, the reaction was heated at $60^{\circ} \mathrm{C}$ for $24 \mathrm{~h}$, neutralized with saturated $\mathrm{Na}_{2} \mathrm{CO}_{3}$ solution and extracted with ethyl acetate $(3 \times 5 \mathrm{~mL})$. The organic phases were combined, dried, filtered, and concentrated under reduced pressure. Compounds $\mathbf{2 b}$ to $\mathbf{2 d}$ were obtained in $96-98 \%$ yield.

Finally, the productions of the azides, $\mathbf{3 b} \mathbf{b}-\mathbf{3 d}$, were performed by transferring the azido group of $\mathrm{TfN}_{3}$ to the amino acid ethyl esters $(\mathbf{2 b - 2 d})$. In a round-bottom flask, $3 \mathrm{~mL}$ of $\mathrm{TfN}_{3}$ solution in DCM were added dropwise to a solution of the corresponding amino acid ester $(0.24 \mathrm{mmol})$, $\mathrm{NaHCO}_{3}(2.4 \mathrm{mmol}), \mathrm{CuSO}_{4} .5 \mathrm{H}_{2} \mathrm{O}(0.024 \mathrm{mmol})$ in $2 \mathrm{~mL}$ of distilled water and methanol 1:1 (v/v). The reaction was kept for $24 \mathrm{~h}$ at room temperature and then extracted with ethyl acetate or DCM $(3 \times 5 \mathrm{~mL})$, dried, filtered, and concentrated to $2 \mathrm{~mL}$ for subsequent use in the respective triazole synthesis. ${ }^{54}$

\section{4-(2-Azidoethyl)phenol (3e) preparation}

Azide 3e was obtained from 4-(2-bromoethyl)phenol (2e), which was previously prepared through bromination of tyrosol according to the methodology described by
Bousada et al. ${ }^{32}$ Briefly, to produce $2 \mathrm{e}, 2.49 \mathrm{mmol}$ of tyrosol and $25 \mathrm{~mL}$ of $48 \% \mathrm{HBr}(\mathrm{m} / \mathrm{m})$ were added to a reaction flask and kept to react under stirring for $17 \mathrm{~h}$ at $70-80^{\circ} \mathrm{C}$. Then, the reaction mixture was extracted with DCM $(4 \times 20 \mathrm{~mL})$; the organic phases were combined, dried over anhydrous $\mathrm{MgSO}_{4}$, filtered, and concentrated on a rotary evaporator. The solid residue was subjected to column chromatography on silica gel eluted with hexane/ethyl acetate $(5: 1 \mathrm{v} / \mathrm{v})$, affording compound $\mathbf{2 e}$, in the form of a white solid in $68 \%$ yield. Then, compound $2 \mathrm{e}(0.55 \mathrm{mmol})$, sodium azide $(0.55 \mathrm{mmol})$, and $1 \mathrm{~mL}$ of dimethylacetamide (DMAC) were allowed to react in a round-bottomed flask under stirring for $5 \mathrm{~h}$ at room temperature. The reaction was then worked-up using ethyl acetate $(3 \times 5 \mathrm{~mL})$, dried, and filtered to afford a solution of $\mathbf{3 e}(2 \mathrm{~mL}$ in $\mathrm{DCM})$.

\section{Coumarin propargylation}

Synthesis of the alkyne (5) was performed by propargylation of coumarin (4) according to the method reported by Bousada et al. ${ }^{32}$ For this, anhydrous potassium carbonate ( $2 \mathrm{mmol}$ ) was added over a solution of 7-hydroxy4-methylcoumarin 4 (1 mmol) in anhydrous acetonitrile $(2 \mathrm{~mL})$ in a round-bottomed flask. The mixture was kept under stirring at room temperature and under nitrogen atmosphere. After 5 to $10 \mathrm{~min}, 165 \mu \mathrm{L}$ of propargyl bromide solution in toluene $(80 \% \mathrm{~m} / \mathrm{m}, 1.5 \mathrm{mmol})$ was added and the mixture was kept under stirring at $50{ }^{\circ} \mathrm{C}$ for $24 \mathrm{~h}$. After cooling to room temperature, acetonitrile was evaporated; ethyl acetate was added, filtered and concentrated under reduced pressure.

4-Methyl-7-(prop-2-yn-1-yloxy)-2H-chromen-2-one (5)

Beige solid; yield 77\%; Rf (hexane/EtOAc 1:1) 0.70; $\mathrm{mp}$ 131.5-133.1 ${ }^{\circ} \mathrm{C}$; IR (ATR) v / $\mathrm{cm}^{-1} 3302,2140,1717$, $1605,1261,1011 ;{ }^{1} \mathrm{H}$ NMR $\left(300 \mathrm{MHz}, \mathrm{CDCl}_{3}\right) \delta 2.39(\mathrm{~d}$, $3 \mathrm{H}, J 1.1 \mathrm{~Hz}), 2.57$ (t, 1H, J 2.4 Hz), $4.75(\mathrm{~d}, 2 \mathrm{H}, J 2.4 \mathrm{~Hz}$ ), $6.14(\mathrm{~d}, 1 \mathrm{H}, J 1.1 \mathrm{~Hz}), 6.90-6.94(\mathrm{~m}, 2 \mathrm{H}), 7.51(\mathrm{~d}, 1 \mathrm{H}$, $J 9.5 \mathrm{~Hz}) ;{ }^{13} \mathrm{C}$ NMR $\left(75 \mathrm{MHz}, \mathrm{CDCl}_{3}\right) \delta 18.7,56.2,76.5$, 77.4, 102.1, 112.4, 112.7, 114.3, 125.7, 152.6, 155.0, 160.3, 161.2; HRMS (ESI) $\mathrm{m} / z$, calcd. for $\mathrm{C}_{13} \mathrm{H}_{10} \mathrm{O}_{3}[\mathrm{M}+\mathrm{H}]^{+}$: 215.0703, found: 215.0712 .

\section{General procedure for the preparation of triazoles}

Coumarin-triazole-amino acid esters hybrids (6-10) were produced by reacting propargylated coumarin (5) with amino acid esters according to the methodology described by Kumari et al. ${ }^{42}$ with modifications.

Alkyne 5 (1.0 eq.), sodium ascorbate (0.40 eq.) and $\mathrm{Cu}_{2} \mathrm{SO}_{4} \cdot 5 \mathrm{H}_{2} \mathrm{O}$ (0.20 eq.) were transferred to a round- 
bottomed flask, followed by addition of 1.4 eq. of azide (3a-3e), $0.5 \mathrm{~mL}$ of distilled water, and $2.0 \mathrm{~mL}$ of solvent (ethyl ether to 6, DCM to $\mathbf{8}$, ethyl acetate to $\mathbf{7}$ and $\mathbf{9}$, and DMAC to 10). The reaction mixture was stirred vigorously at room temperature for $14 \mathrm{~h}$. The aqueous layer was extracted with ethyl acetate $(3 \times 5 \mathrm{~mL})$, filtered, concentrated under reduced pressure, and purified by chromatography on silica gel eluted with hexane/ethyl acetate $(1: 1 \mathrm{v} / \mathrm{v})$ until finally being concentrated under reduced pressure.

Ethyl 2-(4-(((4-methyl-2-oxo-2H-chromen-7-yl)oxy)methyl)$1 H-1,2,3-$ triazol-1-yl)acetate (6)

White solid; yield 86\%; Rf (hexane/EtOAc 2:1) 0.40; mp 130.2-130.9 ${ }^{\circ} \mathrm{C}$; IR (ATR) v / $\mathrm{cm}^{-1} 3154,2925,1747$, $1717,1608,1260,1069 ;{ }^{1} \mathrm{H}$ NMR $\left(300 \mathrm{MHz}, \mathrm{CDCl}_{3}\right) \delta 1.29$ (t, 3H, J 7.1 Hz), 2.38 (s, 3H), 4.26 (q, 2H, J 7.1 Hz), 5.18 $(\mathrm{s}, 2 \mathrm{H}), 5.26(\mathrm{~s}, 2 \mathrm{H}), 6.13(\mathrm{~s}, 1 \mathrm{H}), 6.90(\mathrm{~d}, 1 \mathrm{H}, J 2.5 \mathrm{~Hz})$, 6.93 (dd, 1H, $J$ 8.6, $2.5 \mathrm{~Hz}), 7.50$ (d, 1H, $J 8.6 \mathrm{~Hz}), 7.82$ $(\mathrm{s}, 1 \mathrm{H}) ;{ }^{13} \mathrm{C}$ NMR $\left(75 \mathrm{MHz}, \mathrm{CDCl}_{3}\right) \delta 14.1,18.7,50.9$, 62.2, 62.6, 102.1, 112.2, 112.4, 114.1, 124.5, 125.7, 143.5, 152.5, 155.1, 161.2, 166.2; HRMS (ESI) $\mathrm{m} / z$, calcd. for $\mathrm{C}_{17} \mathrm{H}_{17} \mathrm{~N}_{3} \mathrm{O}_{5}[\mathrm{M}+\mathrm{H}]^{+}:$344.1241, found: 344.1229 .

(S)-Ethyl 3-(4-hydroxyphenyl)-2-(4-(((4-methyl-2-oxo$2 H$-chromen-7-yl)oxy)methyl)-1H-1,2,3-triazol-1-yl) propanoate (7)

Resinous solid; yield 70\%; Rf (hexane/EtOAc 1:1) 0.20; $\left.[\alpha]_{D}\right]^{25.5}-36.4\left(c 1.1, \mathrm{CH}_{3} \mathrm{OH}\right.$ ); IR (ATR) $v / \mathrm{cm}^{-1} 3500-3000$, $3175,2928,1714,1613,1232,1146,1059 ;{ }^{1} \mathrm{H}$ NMR $\left(300 \mathrm{MHz}, \mathrm{CDCl}_{3}\right) \delta 1.18$ (t, 3H, J 7.0 Hz), 2.35 (s, 3H), 3.33 (d, 2H, J 7.2 Hz), 4.19 (q, 2H, J 7.0 Hz), 5.18 (d, 2H, $J 2.6 \mathrm{~Hz}), 5.49(\mathrm{t}, 1 \mathrm{H}, J 7.2 \mathrm{~Hz}), 6.11(\mathrm{~s}, 1 \mathrm{H}), 6.60(\mathrm{~d}, 1 \mathrm{H}$, $J 2.5 \mathrm{~Hz}), 6.63(\mathrm{~d}, 2 \mathrm{H}, J 8.6 \mathrm{~Hz}), 6.72(\mathrm{~d}, 2 \mathrm{H}, J 8.6 \mathrm{~Hz})$, 6.88 (dd, 2H, J 8.8, 2.5 Hz), $7.45(\mathrm{~d}, 1 \mathrm{H}, J 8.8 \mathrm{~Hz}), 7.52$ (s, $1 \mathrm{H}) ;{ }^{13} \mathrm{C}$ NMR $\left(75 \mathrm{MHz}, \mathrm{CDCl}_{3}\right) \delta 14.1,18.8,29.7$, 62.5, 62.6, 64.3, 101.7, 111.9, 113.7, 114.0, 116.0, 123.3, $125.8,130.0,142.7,153.5,154.8,155.8,161.3,162.1$, 168.2; HRMS (ESI) $m / z$, calcd. for $\mathrm{C}_{24} \mathrm{H}_{23} \mathrm{~N}_{3} \mathrm{O}_{6}[\mathrm{M}+\mathrm{H}]^{+}$: 450.1660, found: 450.1642 .

(S)-Ethyl 2-(4-(((4-methyl-2-oxo-2H-chromen-7-yl)oxy) methyl)-1H-1,2,3-triazol-1-yl)-3-phenylpropanoate (8)

Light orange oil; yield 93\%; Rf (hexane/EtOAc 1:1) $0.50 ;[\alpha]_{D}^{25.5}-32.3\left(c 1.3, \mathrm{CHCl}_{3}\right)$; IR (ATR) $v / \mathrm{cm}^{-1} 3150$, 2982, 1716, 1610, 1070; ${ }^{1} \mathrm{H}$ NMR (300 MHz, $\left.\mathrm{CDCl}_{3}\right) \delta 1.19$ (t, 3H, J 7.1 Hz), 2.39 (d, 3H, J 1.3 Hz), 3.47-3.49 (m, 2H), 4.19 (q, 2H, J 7.1 Hz), 5.29 (s, 2H), 5.57-5.60 (m, 1H), 6.14 (d, 1H, J 1.3 Hz), 6.88 (d, 1H, J 2.5 Hz), 6.92 (dd, $1 \mathrm{H}, J$ 8.9, $2.5 \mathrm{~Hz}), 6.99-7.02(\mathrm{~m}, 2 \mathrm{H}), 7.18-7.21(\mathrm{~m}, 3 \mathrm{H})$, $7.50(\mathrm{~d}, 1 \mathrm{H}, J 8.9 \mathrm{~Hz}), 7.75$ (s, 1H); ${ }^{13} \mathrm{C}$ NMR $(75 \mathrm{MHz}$,
$\left.\mathrm{CDCl}_{3}\right) \delta 14.0,18.7,39.0,53.5,62.9,64.2,102.1,112.2$, $112.5,114.0,123.2,125.7,127.6,128.9,134.5,142.9$, 152.6, 155.1, 161.1, 161.3, 168.1; HRMS (ESI) $\mathrm{m} / z$, calcd. for $\mathrm{C}_{24} \mathrm{H}_{23} \mathrm{~N}_{3} \mathrm{O}_{5}[\mathrm{M}+\mathrm{H}]^{+}$: 434.1710, found: 434.1713.

(S)-Ethyl 3-(1H-indol-3-yl)-2-(4-(((4-methyl-2-oxo$2 H$-chromen-7-yl)oxy)methyl)-1H-1,2,3-triazol-1-yl) propanoate (9)

Light orange oil; yield 58\%; Rf (hexane/EtOAc 1:1) $0.40 ;[\alpha]_{D}{ }_{D}^{25.5}-29.2\left(c 1.3, \mathrm{CHCl}_{3}\right.$ ); IR (ATR) $v / \mathrm{cm}^{-1} 3289$, 2926, 1705, 1608, 1188; ${ }^{1} \mathrm{H}$ NMR (300 MHz, $\left.\mathrm{CDCl}_{3}\right) \delta$ 1.19 (t, 3H, J 7.1 Hz), 2.32 (d, 3H, $J 1.1 \mathrm{~Hz}), 3.59-3.69$ $(\mathrm{m}, 2 \mathrm{H}), 4.17(\mathrm{q}, 2 \mathrm{H}, J 7.1 \mathrm{~Hz}), 5.14(\mathrm{~s}, 2 \mathrm{H}), 5.61-5.64$ $(\mathrm{m}, 2 \mathrm{H}), 6.09(\mathrm{~d}, 1 \mathrm{H}, J 1.1 \mathrm{~Hz}), 6.70-6.71(\mathrm{~m}, 1 \mathrm{H}), 6.85$ (dd, 1H, J 8.8, 2.5 Hz), 7.02-7.13 (m, 2H), $7.29(\mathrm{~d}, 1 \mathrm{H}$, $J 8.0 \mathrm{~Hz}), 7.40(\mathrm{~d}, 1 \mathrm{H}, J 3.1 \mathrm{~Hz}), 7.42-7.43(\mathrm{~m}, 1 \mathrm{H}), 7.70$ (s, $1 \mathrm{H}) ;{ }^{13} \mathrm{C}$ NMR $\left(75 \mathrm{MHz}, \mathrm{CDCl}_{3}\right) \delta 14.0,18.8,29.1,31.7$, 62.2, 63.5, 101.9, 108.5, 111.6, 112.1, 113.0, 113.3, 117.9, $119.7,122.4,123.4,125.8,126.7,136.1,142.8,153.4$, 154.9, 161.1, 161.7, 168.5; HRMS (ESI) $\mathrm{m} / \mathrm{z}$, calcd. for $\mathrm{C}_{26} \mathrm{H}_{24} \mathrm{~N}_{4} \mathrm{O}_{5}[\mathrm{M}+\mathrm{H}]^{+}:$473.1819, found: 473.1819 .

7-(\{1-[2-(4-Hydroxyphenyl)ethyl]-1H-1,2,3-triazol-4-yl\} methoxy)-4-methyl-2H-chromen-2-one (10)

Beige solid; yield 27\%; Rf (hexane/EtOAc 1:1) 0.17; $\mathrm{mp}$ 181.0-182.6 ${ }^{\circ} \mathrm{C}$; IR (ATR) v / $\mathrm{cm}^{-1} 3272,1689,1611$, 1556, 1516, 1444, 1291, 1149, 1072, 1019, 871, 840, 541, 495; ${ }^{1} \mathrm{H}$ NMR $\left(300 \mathrm{MHz},\left(\left(\mathrm{CD}_{3}\right)_{2} \mathrm{CO}\right) \delta 2.43\right.$ (d, 3H, $J 1.2 \mathrm{~Hz}$ ), 3.12 (t, 2H, J 7.3 Hz), 4.61 (t, 2H, J 7.3 Hz), 5.28 (s, 2H), $6.13(\mathrm{~d}, 1 \mathrm{H}, J 1.2 \mathrm{~Hz}), 6.70-6.73(\mathrm{~m}, 2 \mathrm{H}), 6.97-$ $7.04(\mathrm{~m}, 4 \mathrm{H}), 7.66-7.70(\mathrm{~m}, 1 \mathrm{H}), 7.96(\mathrm{~s}, 1 \mathrm{H}) ;{ }^{13} \mathrm{C}$ NMR (75 MHz, $\left.\left(\mathrm{CD}_{3}\right)_{2} \mathrm{CO}\right) \delta 18.6,36.4,52.3,62.9,102.6,112.6$, 113.4, 116.3, 125.1, 127.1, 129.2, 130.7, 143.2, 153.8, 156.2, 157.1, 161.6, 162.1; HRMS (ESI) $\mathrm{m} / \mathrm{z}$, calcd. for $\mathrm{C}_{21} \mathrm{H}_{19} \mathrm{~N}_{3} \mathrm{O}_{4}[\mathrm{M}+\mathrm{H}]^{+}:$378.1448, found: 378.1441 .

The characterization of the triazole 7-(\{1-[2-(4-hydroxyphenyl)ethyl]-1H-1,2,3-triazol4-yl \}methoxy)-4-methyl-2H-chromen-2-one (10) is in accordance with Bousada et al. ${ }^{32}$ and used as a control on enzymatic inhibition.

General procedure for the synthesis of amino acid-coumarin derivatives

The synthesis of the hybrids of coumarin and amino acids using the triazole ring as linker (11-14) was carried out through hydrolysis of the corresponding amino acid esters derivatives 6-9 according to the methodology described by Kumari et al. ${ }^{42}$ To the triazole $(0.23-0.32 \mathrm{mmol})$ and ethanol solution at $0{ }^{\circ} \mathrm{C}$, a $20 \%(\mathrm{~m} / \mathrm{v}) \mathrm{NaOH}$ solution $(5 \mathrm{~mL})$ was added dropwise. 
The reaction was stirred for $3 \mathrm{~h}$ at room temperature. The ethanol was completely concentrated under reduced pressure to afford the corresponding salt of the acid and the $\mathrm{pH}$ was adjusted to 1.0 using concentrated $\mathrm{HCl}$ to obtain the corresponding carboxylic acid. The aqueous layer was extracted with ethyl acetate $(3 \times 5 \mathrm{~mL})$. The organic layers were combined, dried over $\mathrm{MgSO}_{4}$, filtered, and concentrated under reduced pressure.

2-(4-(((4-Methyl-2-oxo-2H-chromen-7-yl)oxy)methyl)1H-1,2,3-triazol-1-yl)acetic acid (11)

Light beige solid; yield 57\%; Rf (methanol) 0.0; mp 110.5-111.2 ${ }^{\circ} \mathrm{C}$; IR (ATR) $v / \mathrm{cm}^{-1}$ 3500-2800, 1688, 1617, 1608, 1241, 1150; ${ }^{1} \mathrm{H}$ NMR (300 MHz, DMSO- $d_{6}$ ) $\delta 2.40(\mathrm{~d}, 3 \mathrm{H}, J 1.2 \mathrm{~Hz}), 5.30(\mathrm{~s}, 2 \mathrm{H}), 5.31(\mathrm{~s}, 2 \mathrm{H}), 6.23$ (d, 1H, J 1.2 Hz), 7.05 (dd, 1H, J 8.9, 2.6 Hz), 7.17 (d, 1H, $J 2.6 \mathrm{~Hz}), 7.70(\mathrm{~d}, 1 \mathrm{H}, J 8.9 \mathrm{~Hz}), 8.29(\mathrm{~s}, 1 \mathrm{H}) ;{ }^{13} \mathrm{C} \mathrm{NMR}$ $\left(75 \mathrm{MHz}, \mathrm{DMSO}-d_{6}\right) \delta 18.7,51.2,62.0,102.0,111.7$, $113.1,113.9,126.9$, 127.0, 129.3, 153.9, 155.1, 161.5, 162.2, 169.1; HRMS (ESI) $\mathrm{m} / z$, calcd. for $\mathrm{C}_{15} \mathrm{H}_{13} \mathrm{~N}_{3} \mathrm{O}_{5}$ $[\mathrm{M}+\mathrm{H}]^{+}:$316.0928, found: 316.0907 .

(S)-3-(4-Hydroxyphenyl)-2-(4-(((4-methyl-2-oxo$2 H$-chromen-7-yl)oxy)methyl)-1 H-1,2,3-triazol-1-yl) propanoic acid (12)

Brown oil; yield 98\%; Rf (methanol) $0.7 ;[\alpha]_{D}^{25.5}-8.9$ (c 0.9, $\mathrm{CH}_{3} \mathrm{OH}$ ); IR (ATR) $v / \mathrm{cm}^{-1} 3600-2800,2954,2923$, 2853, 1717, 1612, 1148; ${ }^{1} \mathrm{H}$ NMR (300 MHz, DMSO- $\left.d_{6}\right)$ $\delta 2.38(\mathrm{~d}, 3 \mathrm{H}, J 1.1 \mathrm{~Hz}), 3.33-3.41(\mathrm{~m}, 2 \mathrm{H}), 5.21(\mathrm{~s}, 2 \mathrm{H})$, 5.60-5.65 (m, 2H), 6.49 (s, 1H), 6.51 (dd, 2H, J 8.8, 2.4 Hz), $6.86(\mathrm{dd}, 2 \mathrm{H}, J$ 8.8, $2.4 \mathrm{~Hz}), 7.00$ (dd, 1H, J 8.9, $2.5 \mathrm{~Hz})$, $7.11(\mathrm{~d}, 1 \mathrm{H}, J 2.5 \mathrm{~Hz}), 7.65$ (d, 1H, J 8.9 Hz), 8.34 (bs, 1H), $9.25(\mathrm{~s}, 1 \mathrm{H}, \mathrm{OH}) ;{ }^{13} \mathrm{C} \mathrm{NMR}\left(75 \mathrm{MHz}, \mathrm{DMSO}-d_{6}\right) \delta 18.6$, 36.4, 62.0, 64.3, 102.0, 111.8, 113.1, 113.8, 115.5, 125.6, $126.6,126.9,130.2,142.0,153.9,155.1,156.5,160.7$, 161.4, 170.3; HRMS (ESI) $\mathrm{m} / z$, calcd. for $\mathrm{C}_{22} \mathrm{H}_{19} \mathrm{~N}_{3} \mathrm{O}_{6}$ $[\mathrm{M}+\mathrm{H}]^{+}$: 422.1347, found: 422.1323 .

(S)-2-(4-(((4-Methyl-2-oxo-2H-chromen-7-yl)oxy)methyl)1H-1,2,3-triazol-1-yl)-3-phenylpropanoic acid (13)

Brown oil; yield 98\%; Rf (methanol) 0.5; $[\alpha]_{D}^{25.5}-4.0$ (c 1.0, $\mathrm{CHCl}_{3}$ ); IR (ATR) v / cm $\mathrm{cm}^{-1} 3300-2700,3150,2928$, 1717, 1610, 1265, 1143, 1071; ${ }^{1} \mathrm{H}$ NMR (300 MHz, DMSO- $\left.d_{6}\right) \delta 2.37(\mathrm{~d}, 3 \mathrm{H}, J 1.0 \mathrm{~Hz}), 3.42-3.55(\mathrm{~m}, 2 \mathrm{H})$, $5.20(\mathrm{~d}, 2 \mathrm{H}, J$ 2.6), 5.73-5.78 (m, 1H), 6.21 (s, 1H), 6.97$7.01(\mathrm{~m}, 2 \mathrm{H}), 7.07$ (d, 1H, J 2.2 Hz), 7.09-7.12 (m, 5H), 7.65 (d, $1 \mathrm{H}, J 8.8 \mathrm{~Hz}), 8.35$ (bs, $1 \mathrm{H}) ;{ }^{13} \mathrm{C} \mathrm{NMR}(75 \mathrm{MHz}$, DMSO- $\left.d_{6}\right) \delta 18.6,37.0,62.0,63.8,102.0,111.7,113.2$, $113.8,125.7,126.9,127.1,128.7,129.2$, 136.6, 142.1, 153.9, 155.1, 160.7, 161.4, 170.2; HRMS (ESI) $\mathrm{m} / \mathrm{z}$, calcd. for $\mathrm{C}_{22} \mathrm{H}_{19} \mathrm{~N}_{3} \mathrm{O}_{5}[\mathrm{M}+\mathrm{H}]^{+}$: 406.1397, found: 406.1394 .
(S)-3-(1H-Indol-3-yl)-2-(4-(((4-methyl-2-oxo-2H-chromen7-yl)oxy)methyl)-1 H-1,2,3-triazol-1-yl)propanoic acid (14)

Brown oil; yield 87\%; Rf (methanol) 0.8; $[\alpha]_{D}{ }^{25.5}-11.4$ (c 0.7, $\mathrm{CH}_{3} \mathrm{OH}$ ); IR (ATR) $v / \mathrm{cm}^{-1} 3500-2700,2924$, 1716, 1696, 1606, 1266, 1141, 1070; ${ }^{1} \mathrm{H}$ NMR (300 MHz, DMSO- $\left.d_{6}\right) \delta 2.37(\mathrm{~d}, 3 \mathrm{H}, J 1.1 \mathrm{~Hz}), 3.64-3.66(\mathrm{~m}, 2 \mathrm{H})$, $5.19(\mathrm{~s}, 2 \mathrm{H}), 5.69-5.72(\mathrm{~m}, 1 \mathrm{H}), 6.21(\mathrm{~s}, 1 \mathrm{H}), 6.91(\mathrm{~d}, 1 \mathrm{H}$, $J$ 2.5 Hz), 6.94-6.96 (m, 1H), 7.01-7.03 (m, 2H), 7.11 (d, $1 \mathrm{H}, J 2.5 \mathrm{~Hz}), 7.26-7.29(\mathrm{~m}, 1 \mathrm{H}), 7.48$ (d, 1H, J 7.8 Hz), $7.65(\mathrm{~d}, 1 \mathrm{H}, J 8.9 \mathrm{~Hz}), 8.40(\mathrm{~s}, 1 \mathrm{H}), 10.81(\mathrm{~s}, 1 \mathrm{H}) ;{ }^{13} \mathrm{C} \mathrm{NMR}$ $\left(75 \mathrm{MHz}, \mathrm{DMSO}-d_{6}\right) \delta 19.7,28.8,63.0,64.5,102.7,109.6$, $112.4,112.5,113.7,114.5,119.0,119.6,122.1,124.7$, $126.1,127.5,127.7,136.9,142.5,154.3,155.5,161.0$, 161.8, 170.8; HRMS (ESI) $\mathrm{m} / z$, calcd. for $\mathrm{C}_{24} \mathrm{H}_{20} \mathrm{~N}_{4} \mathrm{O}_{5}$ $[\mathrm{M}+\mathrm{H}]^{+}:$445.1506, found: 445.1504 .

\section{Molecular docking}

Molecular docking was performed using AutoDockVina ${ }^{\odot}$ 1.1.2 ${ }^{57}$ software following Ferreira et al.,${ }^{58}$ with adaptations.

The receptor was the acetylcholinesterase of the species Torpedo californica, obtained from the protein database (Protein Data Bank, code: 6G1U, Galdeano et al., ${ }^{59} 1.79 \AA$ ) in PDB format. The receptor edition, including removal of water molecules, the addition of non-polar hydrogen atoms and calculation of the protein charges was done with AutoDockTools ${ }^{\oplus}$ software. ${ }^{60}$ The file was converted to the PDBQT (Protein Data Bank, partial charge (Q), and atom type (T)) format.

Ligands, compounds developed in the present work, were drawn in Marvin Sketch ${ }^{\odot} 17.28 .0^{49}$ software, with all hydrogens shown. The files were saved in 3D in PDB format. PyRx ${ }^{\oplus}$ Python Prescription $0.8^{61}$ software was used to convert the files to the PDBQT format.

The possible inhibitors were anchored in the enzyme using the AutoDockVina ${ }^{\odot} 1.1 .2^{57}$ software. A rectangular base prism was created so that the ligands could interact throughout the protein adopting the non-directed docking strategy. The dimensions of the prism were $66 \times 70 \times 74 \AA$ (axes $x, y$ and $z$, respectively), with center at $x=-3.333$, $y=2.167$ and $z=20.917 \AA$. Pharmacophore maps were designed in BIOVIA Discovery Studio 2016 16.1.0.15350. ${ }^{62}$

\section{AChE inhibition assay}

AChE (Electrophorus electricus, type VI, Sigma Aldrich, Saint Louis, Missouri, USA) inhibition evaluation was performed by spectrophotometric assay in a 96-well microplate (TPP, Trasadingen, Schaffhausen, Switzerland).

Initially, triazole compounds $\mathbf{6}$ to $\mathbf{9}$ were tested. The samples were prepared at the concentration of 
$10000 \mu \mathrm{mol} \mathrm{L}^{-1}$ (HPLC grade methanol, Tedia ${ }^{\circledR}$, São Paulo, Brazil). These samples were subjected to serial dilution in buffer A (Tris- $\mathrm{HCl} 50 \mathrm{mmol} \mathrm{L}^{-1}, \mathrm{pH} 8.0$ ), obtaining intermediate solutions at the concentrations of 2000, 1000, and $500 \mu \mathrm{mol} \mathrm{L}{ }^{-1}$. The concentration of methanol in these samples was adjusted so that all of them had $20 \%(\mathrm{v} / \mathrm{v})$ of this solvent. The assay was performed for three consecutive days, with a triplicate for each compound, including the controls.

The assays were performed according to the methodology proposed by Ellman et al. ${ }^{63}$ with modifications to decrease losses due to the solubility of the compounds. In microtubes, $200 \mu \mathrm{L}$ of bovine serum albumin solution ( $0.1 \%$ BSA in Tris- $\mathrm{HCl}$ buffer), $100 \mu \mathrm{L}$ of acetylthiocholine iodide solution in ultrapure water (14.5 $\left.\mathrm{mmol} \mathrm{L}^{-1}\right), 500 \mu \mathrm{L}$ of 5,5'-dithiobis 2-nitrobenzoic acid solution $\left(3 \mathrm{mmol} \mathrm{L}^{-1}\right.$ of DTNB in Tris-HCl buffer containing $10 \mathrm{mmol} \mathrm{L}^{-1}$ of $\mathrm{NaCl}$ and $20 \mathrm{mmol} \mathrm{L}^{-1}$ of $\mathrm{MgCl}_{2}$ ) and $100 \mu \mathrm{L}$ of the intermediate solutions were added. Negative control was performed using methanol, and both compound $\mathbf{1 0}$ and galantamine were used as positive controls. The tested concentrations of compounds were 200,100 , and $50 \mu \mathrm{mol} \mathrm{L}^{-1}$, including the standard inhibitor 10. Galantamine as tested at $17 \mu \mathrm{mol} \mathrm{L}^{-1}$.

Plate assembly was performed by removing a $225 \mu \mathrm{L}$ aliquot from each microtube, in triplicate. The background was read at $405 \mathrm{~nm}$ wavelength and $30^{\circ} \mathrm{C}$ in a spectrophotometer (Thermoplate, model TP-reader). To perform the kinetic assay $25 \mu \mathrm{L}\left(0.2 \mathrm{U} \mathrm{mL}^{-1}, 0.1 \%\right.$ BSA in buffer A) of the enzyme AChE (Electrophorus electricus type VI) were added and the plate and were read $\left(\lambda=405 \mathrm{~nm}\right.$ at $\left.30^{\circ} \mathrm{C}\right)$ every $5 \mathrm{~min}$ for $25 \mathrm{~min}$. Inhibition of the enzymatic hydrolysis was calculated according to equation 1 , from the difference in absorbance reading obtained in the background (without enzyme) and kinetic assay (20 min with enzyme).

Inhibition $(\%)=100-\frac{[(\mathrm{Ab} \text { kinetic assay }-\mathrm{Ab} \text { background }) \times 100]}{\mathrm{Ab} \text { negative control }}$

where $\mathrm{Ab}$ is the absorbance value.

Subsequently, the esterified triazole compounds 11 to 14 were tested according to the above methodology. However, the concentrations evaluated were only 100 and $50 \mu \mathrm{mol} \mathrm{L}^{-1}$ due to the solubility.

\section{Physico-chemical parameters}

Molar mass $\left(\mathrm{g} \mathrm{mol}^{-1}\right), \mathrm{MlogP}$, and van der Waals volume $\left(\AA^{3}\right)$ were calculated by the MedChem Designer ${ }^{\odot}$ 3.1.0.30, ${ }^{48}$ Marvin Sketch $^{\odot} 17.28 .0^{49}$ and ChemDraw Ultra ${ }^{\odot}$ 12.0.2.1076, ${ }^{50}$ respectively.

\section{Statistical analysis}

Data were expressed as the mean \pm standard deviation. Analysis of variance (ANOVA), and Tukey's post-test were used to compare enzyme inhibition of amino acids connected to the coumarin nucleus via triazole. Nonparametric correlation (Spearman) was used to evaluate physicochemical parameters. $t$-test was used to compare derivatives esterified or not. The software used was GraphPad Prism ${ }^{\circledR} 5.0 .^{64}$

\section{Supplementary Information}

Supplementary information (IR, ${ }^{1} \mathrm{H}$ and ${ }^{13} \mathrm{C}$ NMR and HRMS spectra) is available free of charge at http://jbcs.sbq.org.br as PDF file.

\section{Acknowledgments}

This work was supported by FAPEMIG (Fundação de Amparo à Pesquisa do Estado de Minas Gerais), CAPES (Coordenação de Aperfeiçoamento de Pessoal de Nível Superior), CNPq (Conselho Nacional de Desenvolvimento Científico e Tecnológico) and FINEP (Financiadora de Estudos e Projetos). The authors would like to thank Prof Ricardo J. Alves (Department of Pharmaceutical Products, Federal University of Minas Gerais) for the acquisition of optical activity data.

\section{Author Contributions}

Bianca L. de Sousa was responsible for conceptualization, methodology, investigation, resources, writing-original draft, writing-review and editing; João P. V. Leite for data curation, methodology, investigation, writing-review and editing; Tiago A. O. Mendes for data curation, investigation, visualization, software, validation, writing original drafty, writing-review and editing; Eduardo V. V. Varejão for resources, investigation, writing-review and editing; Anna C. S. Chaves for methodology, resources, writingreview and editing; Júnio G. da Silva for methodology, resources, writing-original draft; writing-review and editing; Ana P. Agrizzi for data curation, methodology, investigation, writing-review and editing; Priscila G. Ferreira for data curation, investigation, visualization, software, validation, writing-review and editing; Eduardo J. Pilau for methodology, writing-review and editing; Evandro Silva for methodology, writing-review and editing; Marcelo H. Santos for project administration, funding acquisition, supervision investigation, resources, writingoriginal draft, writing-review and editing. 


\section{References}

1. Hussein, D. M.; Al-juboory, S. B.; Razzak Mahmood, A. A.; Orient. J. Chem. 2017, 33, 768.

2. Thakur, A.; Singla, R.; Jaitak, V.; Eur. J. Med. Chem. 2015, 101, 476.

3. Cerqueira, A. F. R.; Neves, M. G. P. M. S.; Molecules 2017, 22, 994.

4. López-Rojas, P.; Janeczko, M.; Kubiński, K.; Amesty, Á.; Masłyk, M.; Estévez-Braun, A.; Molecules 2018, 23, 199.

5. de Souza, G. A.; da Silva, S. J.; del Cistia, C. N.; PitasseSantos, P.; Pires, L. O.; Passos, Y. M.; Cordeiro, Y.; Cardoso, C. M.; Castro, R. N.; Saint'Anna, C. M. R.; Kümmerle, A. E.; J. Enzyme Inhib. Med. Chem. 2019, 34, 631.

6. Nagamallu, R.; Srinivasan, B.; Ningappa, M. B.; Kumar, A.; Bioorg. Med. Chem. Lett. 2016, 26, 690.

7. Moustafa, E. S.; Swilam, N. F.; Ghanem, O. B.; Hashim, A. N.; Nawwar, M. A.; Lindequist, U. L. M.; Pharmazie 2018, 73, 241.

8. Zhang, L.; Xu, Z.; Eur. J. Med. Chem. 2019, 181, 111587.

9. Kumar, M.; Singla, R.; Dandriyal, J.; Jaitak, V.; Anticancer Agents Med. Chem. 2018, 18, 964.

10. Xu, K.; Wang, J. L.; Chu, M. P.; Jia, C.; J. Mycol. Med. 2019 , $29,28$.

11. Hu, X.; Xu, Z.; Liu, M.; Feng, L.; Zhang, G.; Curr. Top. Med. Chem. 2018, 17, 3219.

12. Mandlik, V.; Patil, S.; Bopanna, R.; Basu, S.; Singh, S.; PLoS One 2016, 11, e0164585.

13. Rosa, I. A.; de Almeida, L.; Alves, K. F.; Marques, M. J.; Fregnan, A. M.; Silva, C. A.; Giacoppo, J. O. S.; Ramalho, T. C.; Carvalho, D. T.; dos Santos, M. H.; Med. Chem. Res. 2017, 26, 131 .

14. Mangasuli, S. N.; Hosamani, K. M.; Devarajegowda, H. C.; Kurjogi, M. M.; Joshi, S. D.; Eur. J. Med. Chem. 2018, 146, 747.

15. Hu, Y.; Zhang, S.; Zhao, F.; Gao, C.; Feng, L.; Eur. J. Med. Chem. 2017, 133, 255.

16. Repsold, B. P.; Malan, S. F.; Joubert, J.; Oliver, D. W.; SAR QSAR Environ. Res. 2018, 29, 231.

17. Yusufzai, S. K.; Khan, M. S.; Sulaiman, O.; Osman, H.; Lamjin, D. N.; Chem. Cent. J. 2018, 12, 128.

18. Ren, Q.; Gao, C.; Xu, Z.; Feng, L.; Liu, M.; Wu, X.; Zhao, F.; Curr. Top. Med. Chem. 2018, 18, 101.

19. Evans, B. E.; Rittle, K. E.; Bock, M. G.; DiPardo, R. M.; Freidinger, R. M.; Whitter, W. L.; Lundell, G. F.; Veber, D. F.; Anderson, P. S.; Chang, R. S.; Lotti, V. J.; Cerino, D. J.; Chen, T. B.; Kling, P. J.; Kunkel, K. A.; Springer, J. P.; Hirshfield, J.; J. Med. Chem. 1988, 31, 2235.

20. Obied, H. K.; Funct. Foods Health Dis. 2013, 3, 230.

21. Lal, K.; Yadav, P.; Kumar, A.; Kumar, A.; Paul, A. K.; Bioorg. Chem. 2018, 77, 236.
22. Torres, F. C.; Gonçalves, G. A.; Vanzolini, K. L.; Merlo, A. A.; Gauer, B.; Holzschuh, M.; Andrade, S.; Piedade, M.; Garcia, S. C.; Carvalho, I.; von Poser, G. L.; Kawano, D. F.; Eifler-Lima, V. L.; Cass, Q. B.; J. Braz. Chem. Soc. 2016, 27, 1541.

23. Dias, M. C. F.; Gularte, T. Q.; Teixeira, R. R.; Santos, J. A. N.; Pilau, E. J.; Mendes, T. A. O.; Demuner, A. J.; dos Santos, M. H.; J. Braz. Chem. Soc. 2019, 30, 97.

24. Osorio, L. S.; Ionta, M.; Demuner, A. J.; de Sousa, B. L.; Ferraz, G. O.; Varejão, E. V. V.; Ferreira-Silva, G. A.; Pilau, E. J.; Silva, E.; dos Santos, M. H.; J. Braz. Chem. Soc. 2020, 31, 2500.

25. Hou, W.; Luo, Z.; Zhang, G.; Cao, D.; Li, D.; Ruan, H.; Ruan, B. H.; Su, L.; Xu, H.; Eur. J. Med. Chem. 2017, 138, 1042.

26. Torres, L. M. F. C.; Almeida, M. T.; Santos, T. L.; Marinho, L. E. S.; de Mesquita, J. P.; da Silva, L. M.; dos Santos, W. T. P.; Martins, H. R.; Kato, K. C.; Alves, E. S. F.; Liao, L. M.; de Magalhães, M. T. Q.; de Mendonça, F. G.; Pereira, F. V.; Resende, J. M.; Bemquerer, M. P.; Rodrigues, M. A.; Verly, R. M.; Colloids Surf., B 2019, 177, 94.

27. Kodama, T.; Ito, T.; Dibwe, D. F.; Woo, S.-Y.; Morita, H.; Bioorg. Med. Chem. Lett. 2017, 27, 2397.

28. Brand, S.; Ko, E. J.; Viayna, E.; Thompson, S.; Spinks, D.; Thomas, M.; Sandberg, L.; Francisco, A. F.; Jayawardhana, S.; Smith, V. C.; Jansen, C.; de Rycker, M.; Thomas, J.; MacLean, L.; Osuna-Cabello, M.; Riley, J.; Scullion, P.; Stojanovski, L.; Simeons, F. R. C.; Epemolu, O.; Shishikura, Y.; Crouch, S. D.; Bakshi, T. S.; Nixon, C. J.; Reid, I. H.; Hill, A. P.; Underwood, T. Z.; Hindley, S. J.; Robinson, S. A.; Kelly, J. M.; Fiandor, J. M.; Wyatt, P. G.; Marco, M.; Miles, T. J.; Read, K. D.; Gilbert, I. H.; J. Med. Chem. 2017, 60, 7284.

29. Masood, M. M.; Hasan, P.; Tabrez, S.; Ahmad, M. B.; Yadava, U.; Daniliuc, C. G.; Sonawane, Y. A.; Azam, A.; Rub, A.; Abid, M.; Bioorg. Med. Chem. Lett. 2017, 27, 1886.

30. Banerji, B.; Chandrasekhar, K.; Sreenath, K.; Roy, S.; Nag, S.; das Saha, K.; ACS Omega 2018, 3, 16134.

31. Thirusangu, P.; Vigneshwaran, V.; Prashanth, T.; Vijay Avin, B. R.; Malojirao, V. H.; Rakesh, H.; Khanum, S. A.; Mahmood, R.; Prabhakar, B. T.; Angiogenesis 2017, 20, 55.

32. Bousada, G. M.; de Sousa, B. L.; Furlani, G.; Agrizzi, A. P.; Ferreira, P. G.; Leite, J. P. V.; Mendes, T. A. O.; Varejão, E. V. V.; Pilau, E. J.; dos Santos, M. H.; Comput. Biol. Chem. 2020, $88,107359$.

33. Moradi, A.; Faraji, L.; Nadri, H.; Hasanpour, Z.; Moghadam, F. H.; Pakseresht, B.; Golshani, M.; Moghimi, S.; Ramazani, A.; Firoozpour, L.; Khoobi, M.; Foroumadi, A.; Med. Chem. Res. 2018, 27, 1741.

34. Goron, A.; Moinard, C.; Amino Acids 2018, 50, 969.

35. Chung, D.; Kim, S. Y.; Ahn, J.; Sci. Rep. 2017, 7, 2578.

36. Andany, M. A.; Adeva, G. S.; Rodríguez, E. A.; Amino Acids 2018, 50, 11.

37. Katiyar, S. S.; Kushwah, V.; Dora, C. P.; Patil, R. Y.; Jain, S.; AAPS PharmSciTech 2019, $20,1$. 
38. Vale, N.; Ferreira, A.; Matos, J.; Fresco, P.; Gouveia, M.; Molecules 2018, 23, 2318.

39. Küçükbay, F. Z.; Küçükbay, H.; Tanc, M.; Supuran, C. T.; J. Enzyme Inhib. Med. Chem. 2016, 31, 1198.

40. Faty, R. A. M.; Mourad, A. K.; Elmotaleb, R. M. A.; Radewan, R. M.; Res. Chem. Intermed. 2018, 44, 1551.

41. Pandiakumar, A. K.; Sarma, S. P.; Samuelson, A. G.; Tetrahedron Lett. 2014, 55, 2917.

42. Kumari, S.; Joshi, S.; Shakoor, S. M. A.; Agarwal, D. S.; Panda, S. S.; Pant, D. D.; Sakhuja, R.; Aust. J. Chem. 2015, 68, 1415.

43. Bajda, M.; Więckowska, A.; Hebda, M.; Guzior, N.; Sotriffer, C.; Malawska, B.; Int. J. Mol. Sci. 2013, 14, 5608.

44. Müller, I.; Acta Crystallogr., Sect. D: Struct. Biol. 2017, 73, 79.

45. Chen, Z.; Lu, D.; Weber, S. G.; J. Pharm. Sci. 2009, 98, 229.

46. Chavarria, D.; Fernandes, C.; Aguiar, B.; Silva, T.; Garrido, J.; Remião, F.; Oliveira, P. J.; Uriarte, E.; Borges, F.; Molecules 2019, 24, 4405.

47. Rajan, V. K.; Ragi, C.; Muraleedharan, K.; Heliyon 2019, 5, $\mathrm{e} 02115$.

48. MedChem Designer ${ }^{\circledR}$, version 3.1.0.30; Simulations Plus, Inc, Lancaster, USA, 2011.

49. Marvin Sketch ${ }^{\circledR}$, version 17.28.0; ChemAxon, Budapest, Hungary, 2017.

50. Cousins, K. R.; J. Am. Chem. Soc. 2011, 133, 8388.

51. Dvir, H.; Silman, I.; Harel, M.; Rosenberry, T. L.; Sussman, J. L.; Chem.-Biol. Interact. 2010, 187, 10.

52. Ordentlichs, A.; Baraks, D.; Kronmans, C.; Flashners, Y.; Leitners, M.; Segalls, Y.; Ariel, N.; Cohens, S.; Velans, B.; Shaffermansll, A.; J. Biol. Chem. 1993, 268, 17083.
53. Moustafa, A. H.; El-Seadawy, N. A. M.; Hassan, A. A.; Pasha, S. H.; El-Sayed, H. A.; Shimess, N. A. M.; Hassan, N. A.; Der Chem. Sin. 2017, 8, 313.

54. Robillard, M. S.; Cruell, H.; US pat. 2010/0227798, 2010.

55. Vasella, A.; Witzig, C.; Chiara, J.-L.; Martin-Lomas, M.; Helv. Chim. Acta 1991, 74, 2073.

56. Laulloo, S. J.; Asian J. Chem. 2005, 17, 697.

57. Trott, O.; Olson, A.; J. Comput. Chem. 2010, 31, 455.

58. Ferreira, P. G.; Ferraz, A. C.; Figueiredo, J. E.; Lima, C. F.; Rodrigues, V. G.; Taranto, A. G.; Ferreira, J. M. S.; Brandão, G. C.; Vieira-Filho, S. A.; Duarte, L. P.; de Brito Magalhães, C. L.; de Magalhães, J. C.; Arch. Virol. 2018, 163, 1567.

59. Galdeano, C.; Coquelle, N.; Cieslikiewicz-Bouet, M.; Bartolini, M.; Pérez, B.; Victòria Clos, M.; Silman, I.; Jean, L.; Colletier, J. P.; Renard, P. Y.; Muñoz-Torrero, D.; Molecules 2018, 23, 634.

60. Morris, G. M.; Huey, R.; Lindstrom, W.; Sanner, M. F.; Belew, R. K.; Goodsell, D. S.; Olson, A. J.; J. Comput. Chem. 2009, 30, 2785.

61. PyRx Python Prescription, version 0.8; The Scripps Research Institute, La Jolla, United States, 2008.

62. BIOVIA Discovery Studio, version 16.1.0.15350; Dessault Systèmes Biovia Corp., San Diego, United States, 2016.

63. Ellman, G. L.; Courtney, K. D.; Andres, V.; Featherstone, R. M.; Biochem. Pharmacol. 1961, 7, 88.

64. GraphPad GraphPad Prism ${ }^{\circledR}$, version 5.0; GraphPad Software, San Diego, United States, 2007.

Submitted: August 13, 2020

Published online: November 9, 2020 